\title{
PENCEGAHAN PENYALAHGUNAAN KEWENANGAN PENYIDIK DALAM PENEGAKAN HUKUM TINDAK PIDANA NARKOTIKA
}

\author{
Riza Alifianto Kurniawan \\ Fakultas Hukum Universitas Airlangga, Kampus B \\ Jalan Dharmawangsa Dalam Selatan Surabaya \\ alifriza@,fh.unair.ac.id
}

\begin{abstract}
Narcotic crimes has become attention in Indonesia. Indonesia declared war to the narcotic abuser including the organized crime who run the illegal business. One of the strategy that being implemented is undercover buy and surveillance to the offenders. The strategy gained huge success and could enhance the rate due process for narcotics crimes. On the opposite, the strict implementation of undercover buy and surveillance could trigger the human rights violation and abuse of investigators power. In order to prevent the abuse of power and entrapment of narcotic cases, investigator should follows the good governance rules in investigating cases as a result the due process could be fair and transparent.
\end{abstract}

Keywords : undercover buy, surveillance, discretion power

\begin{abstract}
Abstrak
Tindak Pidana Narkotika sudah menjadi prioritas penegakan hukum di Indonesia. Pemberian kewenangan khusus dalam hal penyidikan tindak pidana narkotika bagi POLRI dan BNN memberikan peluang penegakan hukum yang lebih efektif, akan tetapi luasnya kewenangan penyidikan memberikan peluang juga untuk terjadinya pelanggaran atau penyalagunaan kewenangan apabila tidak diatur atau dievaluasi. Evaluasi kewenangan penyidik dalam sistem peradilan pidana Indonesia dilakukan melalui mekanisme praperadilan. Kewenangan khusus membutuhkan dasar hukum dan aturan main yang khusus pula sehingga lembaga praperadilan dapat digunakan untuk menguji atau memberi perlindungan hak-hak tersangka yang menjalani proses pemeriksaan di tingkat penyidikan dan penuntutan. Metode penelitian yang digunakan adalah menguji konsep kewenangan penyidik tindak pidana narkotika dengan menggunakan peraturan perundang-undangan dan asas-asas umum pemerintahan yang baik.
\end{abstract}

Kata kunci : pembelian terselubung, penyerahan yang diawasi, diskresi

\section{A. Pendahuluan}

Tindak pidana narkotika adalah salah satu dari tindak pidana yang diatur dalam suatu undang undang yang bersifat khusus. Pengaturan secara khusus dalam suatu produk hukum tersendiri menunjukkan tindak pidana narkotika dapat dikategorikan sebagai tindak pidana yang berat.(Atmasasmita, 2010a) Hal ini dapat dilihat bahwa tindak pidana narkotika ancaman pemidanaanya rata-rata lebih dari 5 tahun dan adanya kumulasi pidana pokok.

Undang Undang Narkotika sangat agresif dalam melakukan penegakan hukum terhadap para pelaku penyalaguna narkotika. Kewenangan penyidik dalam perkara tindak pidana narkotika sangat luas dan berpeluang untuk menimbulkan penyimpangan. Salah satu kewenangan penyidik tindak pidana narkotika adalah pembelian terselubung dan penyerahan dibawah pengawasan. Pemberian kewenangan penyidikan ini sebagai tindak lanjut dalam pengungkapan kasus tindak pidana narkotika yang sangat sulit untuk diungkap. Pembelian terselubung dan penyerahan di bawah pengawasan dalam beberapa kasus sangat memberi dampak positif untuk membuka jaringan kejahatan 
penyalaguna narkotika dan kejahatan terorganisasi. Kewenangan penyidikan ini sangat berpotensi untuk disalahgunakan oleh penyidik POLRI atau BNN dalam melakukan penjebakan atau rekayasa perkara. Oleh karena itu, untuk mencegah terjadinya penyalagunaan terhadap hak tersangka maka sangat diperlukan adanya batasan kewenangan penyidik.

Kewenangan penyidik dalam tindak pidana narkotika sangat luas apabila dibandingkan dengan kewenangan penyidik tindak pidana biasa.(Sasangka \& Rosita, 2003) Salah satu kewenangan luas yang dimiliki oleh penyidik tindak pidana narkotika adalah teknik penyidikan pembelian terselubung dan penyerahan dibawah pengawasan. Dua kewenangan dalam teknik penyidikan ini adalah sarana yang diberikan oleh Undang Undang No 35 Tahun 2009 tentang narkotika sebagai kewenangan untuk lebih menjerat pelaku penyalaguna narkotika. Tindak pidana narkotika sangat sulit untuk dijerat pelakunya karena sifat tindak pidana ini sangat terorganisasi. Semua pelaku penyalaguna mempunyai jaringan kejahatan sendirisendiri yang sangat sulit dideteksi oleh aparat penegak hukum.

Teknik pembelian terselubung dan penyerahan dibawah pengawasan diakui sebagai bagian dari kewenangan penyidik berdasarkan pada Undang Undang No 35 Tahun 2009 pasal 79. Penjelasan terkait dua kewenangan ini menjadi tidak jelas karena seperti kewenangan penyidik yang sangat subyektif tergantung dari penilaian penyidik. Dalam pasal 79 disebutkan bahwa pembelian terselubung dan penyerahan yang diawasi dilakukan berdasarkan perintah tertulis dari atasan penyidik. Perintah tertulis dari penyidik untuk menerapkan kewenangan pembelian terselubung dan penyerahan yang diawasi memberikan pelaung untuk pelanggarahan hak tersangka.

Pelanggaran yang mungkin terjadi dalam pembelian terselubung dan penyerahan dibawah pengawasan adalah suatu rekayasa kasus tindak pidana yang dilakukan oleh oknum penyidik(Hieriej, 2012). Rekayasa ini dapat diartikan sebagai bentuk penyalagunaan kekuasaan oleh penyidik dan tidak dapat diukur secara obyektif. Mekanisme yang dilakukan oleh tersangka dalam melindungi hak-haknya adalah melalui lembaga praperadilan yang diatur dalam KUHAP(Chazawi, 2011$)$. Proses praperadilan sebenarnya adalah mekanisme untuk menguji kewenangan penyidikan yang dimiliki oleh BNN khususnya menguji keabsahan teknik pembelian terselubung dan penyerahan dibawah pengawasan.

Sarana yang dapat digunakan dalam melakukan kontrol untuk teknik penyidikan pembelian terselubung dan penyerahan dibawah pengawasan adalah dengan menerapkan asas good governace dalam administrasi penyidikan perkara pidana (Sasangka \& Rosita, 2003). Istilah yang sangat umum dikenal untuk asas ini adalah asas asas umum pemerintahan yang baik. Asas ini memberikan tolak ukur bagi penyidik pada saat melakukan kewenangannya agar tidak memberi pelanggaran kepada pihak lain. Ketentuan tidak tertulis dalam asas good governance dalam penyidikan memberikan ketidakpastian tafsir atau diskresi yang tidak terukur.(Hadjon, Lotulung, Marzuki, Djatmiati, \& Wairocana, 2010) Penelitian ini mencoba memberikan kekosongan hukum dalam pengaturan teknik penyidikan seperti pembelian terselubung dan penyerahan yang diawasi untuk menjaga profesionalitas penegakan hukum tindak pidana narkotika yang tidak melanggar hak asasi manusia.(Hadjon, 1997)

Permasalahan dalam penelitian yang akan dibahas yang pertama adalah apakah batas kewenangan pembelian terselubung dan penyerahan dibawah pengawasan dalam Undang Undang No 35 Tahun 2009 Tentang Narkotika. Permasalahan yang kedua adalah bagaimana perlindungan terhadapa hak tersangka dalam penerapan kewenangan pembelian terselubung dan penyerahan dibawah pengawasan.

\section{B. Metode Penelitian}

Penelitian ini merupakan penelitian hukum (Marzuki, 2004) berdasarkan kepada Undang Undang No 35 Tahun 2009 tentang 
Narkotika dan Undang Undang No 8 Tahun 1981 tentang Hukum Acara Pidana. Penelitian ini menggunakan pendekatan perundang-undangan (statute approach) dan pendekatan konsep (conceptual approach). Pendekatan perundang-undangan merupakan karakter utama dalam penelitian hukum normatif, dengan mengedepankan kajian perundang-undangan dan kajian konsepkonsep hukum yang berkaitan dengan teknik penyidikan dan norma-norma kewenangan penyidik dalam melakukan penyidikan tindak pidana narkotika. Pendekatan kedua yang digunakan adalah Pendekatan konseptual (conceptual approach) merupakan salah satu karakter dalam penelitian hukum normative.(Marzuki, 2004) Konsep perlindungan terhadap hak hak tersangka dan asas-asas umum pemerintahan yang baik sebagai mekanisme perlindungan hak tersangka dalam proses hukum acara pidana. Konsep yang akan dikaji dalam penelitian ini adalah konsep pembelian terselubung dan konsep penyerahan di bawah pengawasan. Kedua konsep ini adalah suatu konsep khusus dalam undang undang narkotika yang belum ada pengaturannya dalam hukum acara pidana.

Sumber Bahan Hukum yang digunakan dalam penelitian ini adalah Bahan hukum primer dalam penelitian ini adalah aturan dalam Undang Undang No 35 Tahun 2009 tentang Narkotika dan Undang Undang No 8 Tahuin 1981 tentang Hukum Acara Pidana. Bahan hukum yan lain yaitu Bahan hukum sekunder yang digunakan dalam penelitian ini adalah karya ilmiah para sarjana seperti buku dan jurnal-jurnal ilmiah, hasil-hasil penelitian, dan putusan pengadilan, wawancara dengan penyidik tindak pidana narkotika baik penyidik dari POLRI maupun BNN (Badan Narkotika Nasional). Wawancara juga akan dilakukan terhadap jaksa penuntut umum yang pernah menangani atau mendakwa terdakwa pelaku tindak pidana narkotika, khususnya tentang penyusunan surat dakwaan dengan mendasarkan pada hasil penyidikan melalui pembelian terselubung dan atau penyerahan di bawah pengawasan. Wawancara ini untuk mendapatkan bahan hukum yang relevan berkaitan dengan penyelesaian penelitian ini.
Prosedur Pengumpulan Bahan Hukum dilakukan dengan Melalui hasil wawancara dari pihak terkait (penyidik dan jaksa penuntut umum) serta hasil penelusuran sumber bahan hukum baik primer maupun sekunder yang telah dikumpulkan akan dilakukan pengolahan bahan hukum. Selanjutnya akan dilakukan analisis bahan hukum guna menjawab seluruh permasalahan yang diajukan dalam penelitian ini.

\section{Hasil Dan Pembahasan}

\section{Batasan Kewenangan Pembelian Terselubung dan Penyerahan yang Diawasi}

Penyelidikan tindak pidana adalah permulaan dari dimulainya suatu proses dalam hukum acara pidana untuk menentukan kebenaran materiil dari dugaan terjadinya suatu peristiwa pidana(Harahap, 2005) . Pengertian penyelidikan dalam Undang Undang no 8 Tahun 1981 Tentang Hukum Acara Pidana mempunyai arti sebagai suatu tindakan penyidik atau penyelidik dalam menentukan apakah laporan atau pengaduan yang diterima dari masyarakat adalah suatu tindak pidana atau bukan (KUHAP, 1981). Dalam tahapan penyelidikan, aparat penegak hukum hanya menilai apakah laporan atau pengaduan masyarakat adalah suatu tindak pidana yang diatur oleh undang undang atau hanya berupa tindakan keperdataan atau administrasi yang bukan merupakan tindak pidana. Tahapan penyelidikan ini merupakan awal dari dimulainya suatu tahapan dalam proses hukum acara agar dapat dikenakan suatu pemidanaan atau tidak terhadap tersangka.

Hukum acara pidana mempunyai beberapa tahapan proses yang berkelanjutan dalam pengungkapan suatu kasus tindak pidana. Tahapan tersebut adalah penyelidikan, penyidikan, penuntutan, dan proses pemeriksaan di pengadilan (Atmasasmita, 2010). Tahapan-tahapan ini mempunyai arti dan tata beracara sendiri yang melibatkan aparat penyidikan seperti POLRI, KPK, dan BNN. Aparat penuntutan seperti kejaksaan, dan Hakim sebagai aparat yang mempunyai kewenangan untuk memberikan putusan peradilan.

Tahapan-tahapan pemeriksaan menurut 
undang undang No 8 Tahun 1981 tentang Hukum Acara Pidana atau bisa disebut sebagai KUHAP, memberikan kewenangankewenangan yang dapat digunakan oleh masing-masing aparat penegak hukum untuk mengungkap suatu kasus tindak pidana. Kewenangan yang secara umum diberikan oleh undang undang terhadap penyidik adalah kewenangan melakukan penangkapan, kewenangan melakukan pemanggilan saksi, kewenangan melakukan penahanan, kewenangan melakukan pemeriksaan surat, kewenangan melakukan penyadapan atau intersepsi, kewenangan menyita barang hasil dan alat tindak pidana, dan perampasan barang-barang tertentu.

Kewenangan penyidik tindak pidana seperti yang diuraikan dalam paragraf sebelumnya sangat berkaitan dengan proses dan teknik pengumpulan alat bukti. Pengertian penyidikan dalam KUHAP adalah segala tindakan untuk mengumpulkan alat bukti agar terang tindak pidana yang dilakukan dan menemukan tersangka. Beranjak dari pengertian penyidikan seperti ini, maka penyidikan mempunyai kewenangan yang sangat luas dan bahkan kewenangan tersebut dapat melanggar hak asasi orang lain. Tetapi selama kewenangan tersebut bersumber pada suatu aturan hukum tertulis atau suatu undang undang maka dapat sah dillakukan atau diterapkan oleh penyidik.

Kewenangan penyidik yang demikian besar sangat erat kaitannya dengan sistem pembuktian yang dianut oleh sistem hukum acara pidana Indonesia. Sistem hukum acara pidana Indonesia menganut sistem pembuktian secara terbatas (Negatief Wettelijk Bewijstheorie)(Harahap, 2005). Dalam membuktikan tindak pidana dan kesalahan terdakwa, hakim tidak hanya berpegang pada alat-alat bukti yang ditentukan dalam undang undang. Hakim mempunyai penilaian subyektif terhadap terdakwa melalui keyakinan yang bersumber pada alat-alat bukti yang ditentukan oleh undang undang. Jadi dalam menentukan kesalahan terdakwa atau mengeluarkan putusan, hakim berpegang kepada alat-alat bukti yang ditentukan oleh undang undang dan keyakinannya untuk menentukan terdakwa bersalah atau tidak.
Kewenangan penyidik dalam tindak pidana narkotika sangat luas apabila dibandingkan dengan kewenangan penyidik tindak pidana biasa. Salah satu kewenangan luas yang dimiliki oleh penyidik tindak pidana narkotika adalah teknik penyidikan pembelian terselubung dan penyerahan dibawah pengawasan. Dua kewenangan dalam teknik penyidikan ini adalah sarana yang diberikan oleh Undang Undang No 35 Tahun 2009 tentang narkotika sebagai kewenangan untuk lebih menjerat pelaku penyalaguna narkotika. Tindak pidana narkotika sangat sulit untuk dijerat pelakunya karena sifat tindak pidana ini sangat terorganisasi. Semua pelaku penyalaguna mempunyai jaringan kejahatan sendirisendiri yang sangat sulit dideteksi oleh aparat penegak hukum.

Teknik pembelian terselubung dan penyerahan dibawah pengawasan diakui sebagai bagian dari kewenangan penyidik berdasarkan pada Undang Undang No 35 Tahun 2009 pasal 79. Penjelasan terkait dua kewenangan ini menjadi tidak jelas karena seperti kewenangan penyidik yang sangat subyektif tergantung dari penilaian penyidik. Dalam pasal 79 disebutkan bahwa pembelian terselubung dan penyerahan yang diawasi dilakukan berdasarkan perintah tertulis dari atasan penyidik. Perintah tertulis dari penyidik untuk menerapkan kewenangan pembelian terselubung dan penyerahan yang diawasi memberikan peluang untuk pelanggaran hak tersangka.

Pelanggaran yang mungkin terjadi dalam pembelian terselubung dan penyerahan dibawah pengawasan adalah suatu rekayasa kasus tindak pidana yang dilakukan oleh oknum penyidik. Rekayasa ini dapat diartikan sebagai bentuk penyalagunaan kekuasaan oleh penyidik dan tidak dapat diukur secara obyektif. Mekanisme yang dilakukan oleh tersangka dalam melindungi hak-haknya adalah melalui lembaga praperadilan yang diatur dalam KUHAP. Proses praperadilan sebenarnya adalah mekanisme untuk menguji kewenangan penyidikan yang dimiliki oleh BNN khususnya menguji keabsahan teknik pembelian terselubung dan penyerahan dibawah pengawasan.

Sarana yang dapat digunakan dalam 
melakukan kontrol untuk teknik penyidikan pembelian terselubung dan penyerahan dibawah pengawasan adalah dengan menerapkan asas good governace dalam administrasi penyidikan perkara pidana . Istilah yang sangat umum dikenal untuk asas ini adalah asas asas umum pemerintahan yang baik. Asas ini memberikan tolak ukur bagi penyidik pada saat melakukan kewenangannya agar tidak memberi pelanggaran kepada pihak lain. Ketentuan tidak tertulis dalam asas good governance dalam penyidikan memberikan ketidakpastian tafsir atau diskresi yang tidak terukur. Penelitian ini mencoba memberikan kekosongan hukum dalam pengaturan teknik penyidikan seperti pembelian terselubung dan penyerahan yang diawasi untuk menjaga profesionalitas penegakan hukum tindak pidana narkotika yang tidak melanggar hak asasi manusia.

\section{Perlindungan Terhadap Hak Tersangka Dalam Penerapan Ke we n a g a n P e m b lia Terselubung Dan Penyerahan Dibawah Pengawasan}

Kepolisian Republik Indonesia (POLRI) sebagai satu lembaga yang telah mandiri memiliki peranan yang amat besar dalam kehidupan masyarakat ataupun dalam konteks kenegaraan. Dengan ruang lingkup tugas yang luas di dalam tubuh kepolisian perlu ada pembagian tugas yang jelas. Dengan demikian adanya beberapa kewenangan POLRI untuk mencegah, menyidik dan memberantas masalah narkoba, lebih khususnya yaitu masalah narkotika. Kewenangan PORI untuk mencegah dan menanggulangi masalah narkotika tercantum dalam Pasal 15 ayat (1) huruf c, dimana POLRI berwenang untuk mencegah dan menanggulangi timbulnya penyakit masyarakat, penyakit masyarakat yang dimaksud dalam hal ini adalah penyalahgunaan narkotika.

KUHAP memberikan pemisahan antara Penyelidik dan Penyidik, namun tugas dan kewajiban hampir sama. Dapat dikatakan bahwa yang menjadi tugas dan kewajiban penyelidik pasti tugas dan kewajiban penyidik pula, akan tetapi yang menjadi tugas dan kewajiban penyidik tidak semua menjadi tugas dan kewajiban penyelidik. Oleh karenanya, seorang penyidik pasti juga seorang penyelidik, namun seorang penyelidik belum tentu ia penyidik. Pada pokoknya semua penyelidik adalah pejabat POLRI.

KUHAP merupakan peraturan bagi proses acara, khususnya acara pidana bagi penegak hukum. Segala bentuk tindakan aparat penegak hukum, utamanya penyidik diatur dalam KUHAP(Harahap, 2005). Pengaturan sedemikian rupa tentu demi menjamin kepastian hukum dan keadilan terhadap seseorang yang sedang melalui proses acara pidana (Anwar, 2011). Kita semua tentu memahami bahwa KUHAP pada dasarnya dibentuk untuk melindungi kepentingan hukum seseorang yang dilaporkan, disangka, didakwa dan dipidana. Perlindungan tersebut adalah perlindungan yang diberikan oleh Negara terhadap kesewenangan aparat penegak hukum dalam hal mereka melalaksanakan upaya paksa.

Berdasarkan Konvensi Palermo tahun 2000, tindak pidana penyalagunaan narkotika yang dilakukan oleh kejahatan terorganisir menjadi salah satu jenis "extraordinary crime." Predikat 'extraordinary crime ini disematkan kepada kejahatan-kejahatan yang ancaman pidananya berat dan memerlukan upaya ekstra dalam pemberantasan dan pencegahannya(Lily, 2015).

Tindak pidana narkotika di Indonesia diatur dalam Undang Undang No 35 Tahun 2009 Tentang Narkotika. Undang undang ini adalah produk hukum ke-3 yang dikeluarkan oleh Republik Indonesia yang bertujuan untuk mencegah dan memberantas penyalagunaan narkotika. Di setiap revisi peraturan narkotika sejak tahun 1976 sampai 2009 memberikan kebijakan yang berbeda untuk menyelesaikan isu-isu pencegahan dan penegakan hukum narkotika untuk mendapatkan efek jera bagi pelaku.

Konsep pembelian terselubung dan penyerahan yang diawasi adalah salah satu upaya paksa yang diberikan oleh undang undang untuk mempermudah penegakan hukum penyalagunaan narkotika. Dua konsep kewenangan penyidik ini dapat disebut juga sebagai suatu kekhususan kewenangan 
penyidik narkotika bila dibandingkan dengan kewenangan penyidik tindak pidana biasa.

Tujuan dalam hukum acara pidana adalah mencari kebenaran materiil dari adanya dugaan tindak pidana yang terjadi untuk dapat mencari pelaku tindak pidana. Tujuan hukum acara pidana adalah suatu idealisme dalam pemberantasan dan penegakan hukum pidana. Tujuan hukum acara pidana yang mencari kebenaran materiil menegasikan bahwa segala ketentuan hukum acara pidana ini mengamanatkan untuk mengungkap sebab, motif, unsur, dan tujuan dari tindak pidana yang dilakukan oleh pelaku.

Kewenangan penyidik dalam mencari alat bukti seringkali bersinggungan dengan hak asasi manusia. Kewenangan penyidik yang terlalu luas berpotensi untuk disalahgunakan dan melanggar hak asasi manusia. Tindak pidana narkotika meskipun diatur dalam suatu undang undang khusus, tidak berarti ada pelanggaran hak asasi manusia dalam melakukan pemberatasan dan pencegahan.

Tindak pidana penyalagunaan narkotika termasuk tindak pidana yang "extraordinary" atau suatu tindak pidana khusus. Kekhususan dari tindak pidana untuk penegakan hukum mebutuhkan suatu upaya $\mathrm{p}$ e $\mathrm{mb}$ e rantas a $\mathrm{n}$ y $\mathrm{ng}$ j u g a khusus(Remmelink, 2003). Salah satu kekhususan dari upaya penegakan hukum ini adalah pembelian terselubung dan penyerahan yang diawasi. Dua upaya paksa ini diberikan oleh undang undang untuk memudahkan penyidik dalam melakukan pemberantasan penyalaguna narkotika agar mudah untuk diberantas. Upaya paksa penyidik narkotika ini memberikan kemudahan dalam mengungkap penyalagunaan narkotika yang dilakukan secara rahasia atau menggunakan jaringan kejahatan yang sulit untuk diungkap atau dipetakan.

Pemberian upaya paksa yang memberikan kewenangan lebih kepada penyidik narkotika juga menimbulkan adanya potensi masalah dalam isu perlindungan hak tersangka. Potensi pelanggaran yang sering terjadi adalah koleksi alat bukti secara melawan hukum dengan berdasarkan pada upaya paksa penyerahan yang diawasi dan pembelian terselubung. Dua potensi pelanggaran ini membutuhkan suatu aturan main atau suatu standar yang obyektif agar tidak terjadi suatu penyalagunaan kewenangan oleh penyidik(Atmasasmita, 2010b). Salah satu standar yang digunakan adalah dengan mengevaluasi setiap diskresi upaya paksa pembelian terselubung dan penyerahan yang diawasi. Selain itu juga perlu diperkuat lembaga prapreradilan yang memberikan kompetensi absolut tambahan untuk mengevalausi pembelian terselubung dan penyerahan yang diawasi agar dapat obyektif u paya paks a y $\mathrm{g}$ diimplementasikan oleh penyidik tindak pidana narkotika.

Salah satu cara untuk mencegah penyalagunaan kewenangan dari penyidik tindak pidana narkotika adalah dengan menerapkan asas-asas pemerintahan yang baik secara ketat dan transparan. Pejabat atau penyidik yang akan menerapkan upaya paksa pembelian terselubung dan seharusnya mempunyai pemahaman tentang kewenangan upaya paksa ini. Penerapan pembelian terselubung dan atau penyerahan yang diawasi oleh penyidik tindak pidana narkotika dapat bebas diterapkan karena termasuk kewenangan penyidik yang subyektif. Subyektifitas dalam penerapan kedua kewenangan didasarkan pada penilaian penyidik (Diskresi)(Hadjon, 1997). Ukuran dalam menilai kewenangan bebas dalam ranah hukum administrasi dapat diuji dengan asas pemerintahan yang baik (AUPB) atau good governance principles.

Diskresi atau kewenangan bebas yang akan dilakukan oleh penyidik tindak pidana narkotika dapat didasarkan pada undang undang kepolisian Undang Undang No 2 Tahun 2002 yang memberikan pedoman kepada aparat kepolisian untuk mencegah diskresi yang dikeluarkan melanggar hal-hal sebagai berikut:

1. tidak bertentangan dengan suatu aturan hukum

2. selaras dengan kewajiban hukum yang mengharuskan tindakan tersebut dilakukan

3. harus patut, masuk akal, dan termasuk dalam lingkungan jabatannya 
4. pertimbangan yang layak berdasarkan pada keadaan yang memaksa, dan

5. menghormati hak asasi manusia lima prinsip pengambilan diskresi upaya paksa pembelian terselubung dan penyerahan yang diawasi seperti diterangkan di atas, dapat dijadikan pedoman bagi penyidik tindak pidana narkotika. 5 prinsip diskresi penyidikan tersebut, sifatnya adalah kumulatif. Semua prinsip harus dapat dipenuhi oleh penyidik pada saat menerapkan upaya paksa.

\section{Simpulan dan Saran}

1. Simpulan

Pemberantasan penyalagunaan narkotika menjadi prioritas untuk digalakkan. Modus penyalagunaan narkotika yang semakin berkembang dan menggunakan jaringan kejahatan membutuhkan strategi dan upaya luar biasa agar dapat diberantas. Tindak pidana narkotika yang dilakukan oleh pelaku kejahatan terorganisasi membutuhkan strategi dan upaya-upaya hukum khusus yang dilakukan oleh penyidik tindak pidana narkotika

\section{Saran}

Kewenangan penegakan hukum tindak pidana narkotika perlu diperluas dengan tujuan mencapai penurunan angka penyalaguna narkotika di Indonesia. Sebagai sebuah kewenangan penyidikan yang besar, penyidik POLRI dan Badan Narkotika Nasional dalam menerapkan kewenangan pembelian terselubung dan penyerahan yang diawasi, harus berhati-hati dan mencegah terjadinya kesewangan-wenangan atau penyalagunaan kewenangan. Penyidik POLRI dan Badan Narkotika Nasional dapat menerapkan asas-asas pemerintahan (good governance principles) yang baik dalam mengukur dan implementasi kewenangan penyidikan tersebut.

\section{DAFTAR PUSTAKA}

Anwar, Y. (2011). Sistem Peradilan Pidana K o n s e p, K o m p on e n, d a n Pelaksanaannya Dalam Penegakan Hukum di Indonesia. Bandung: Widya Padjajaran.
Atmasasmita, romli. (2010a). Globalisasi dan Kejahatan Bisnis. Kencana Prenada Media.

Atmasasmita, romli. (2010b). Sistem Peradilan Pidana Kontemporer. Kencana Prenada Media.

Chazawi, A. (2011). Hukum Pembuktian Tindak Pidana Korupsi. Jakarta: Bayu Media Publishing.

Hadjon, P. mandiri. (1997). Pengantar Hukum Administrasi Indonesia. Gadjah Mada University Press.

Hadjon, P. mandiri, Lotulung, P. E., Marzuki, L., Djatmiati, T. S., \& Wairocana, I. G. N. (2010). Hukum Administrasi Dan Good Governance. Jakarta: Universitas Trisakti.

Harahap, Y. (2005). Hukum Acara Pidana: Penyidikan, Penuntutan, dan Pemeriksaan di Pengadilan. Sinar Grafika.

Hieriej, E. O. S. (2012). Teori dan Hukum Pembuktian. Erlangga.

Lily, R. (2015). Teori Kriminologi Konteks dan Konsekuensi. Kencana Prenada Media.

Marzuki, P. (2004). Penelitian Hukum. Kencana Prenada Media.

Remmelink, jan. (2003). Hukum Pidana. Gramedia Pustaka Utama.

Sasangka, H., \& Rosita, L. (2003). Hukum Pembuktian Dalam Perkara Pidana. Mandar maju. 